\title{
NUTRIENT DISTRIBUTIONS IN AN ESTUARY OF THE ARGENTINE COAST
}

\author{
MARIZA A. ABRAMETO, MERCEDES TORRES \& GILDA RUFFINI \\ Environmental Pollution Laboratory, Río Negro National University, Argentina
}

\begin{abstract}
We performed a discrete sampling that was programmed to research the axial distribution of dissolved nutrients in surface waters of the Negro river estuary in Argentina. The total dissolved nitrogen (TDN) was composed mainly of $\mathrm{NO}_{3}{ }^{-}$and $\mathrm{NH}_{4}{ }^{+}$; but $\mathrm{NO}_{2}{ }^{-}$was not detected. Total dissolved phosphorus (TDP) was in $\mathrm{PO}_{4}^{-3}$ and organic species. We obtained spatial and seasonal comparisons from data collected during 2013 and 2016. Both nutrients showed, by analysis of variance (ANOVA), significant differences among the seasons of the year (TDN $p<0.0001$ and TDP $p<0.001)$. In the internal estuary, the lowest winter levels were $19.4 \mu \mathrm{M} \mathrm{TDN} / \mathrm{L}$, showing that there is a significant difference with autumn levels of $245.6 \mu \mathrm{M}$ TDN/L by LSD Fischer test ( $p=0.05)$; however, the TDN levels in spring were lower than winter at the beginning of the external estuary, and these differences were not significant and could possibly be an indicator of atmospheric removal or re-sedimentation processes in the area. Average TDP values moved in the range between $1.82 \mu \mathrm{M} / \mathrm{L}$ in autumn at the highest, to the lowest values in winter of $0.93 \mu \mathrm{M} / \mathrm{L}$. The Pearson correlation of $\mathrm{N}-\mathrm{NO}_{3}$ and $\mathrm{P}_{-} \mathrm{PO}_{4}$ in $\mathrm{mg} / \mathrm{L}$ to the environmental properties showed a negative correlation with salinity, with a range of 0 to $8 \% \mathrm{pH}$, and positive correlations with dissolved oxygen. These eutrophication conditions, as with other rivers of the world, could be generating biodiversity imbalances.

Keywords: ammonium, Argentina, estuary, nitrates, nitrites, nitrogen, nutrients, oxygen, phosphate, Rio Negro.
\end{abstract}

\section{INTRODUCTION}

The Río Negro river estuary is located towards the southeast of Río Negro province and the south of Buenos Aires province, in Patagonia, Argentina. It presents three different sections, the marine estuary in free connection with the open sea, the middle estuary (characterized by mixed fresh and salty waters), the inner estuary (mostly composed of fresh water, although it is influenced by the tide), while $66 \mathrm{~km}$ is the freshwater area [1]. The chemical composition of the surface waters is of two kinds: one, of the sulphated sodium chloride type and the other, sulphated calcium magnesium. The first corresponds exclusively to the waters of the estuary and the second, the waters of the river zone [2]. The electrical conductivity in the middle estuary is high; $1560-8069 \mu \mathrm{S} \mathrm{cm}^{-1}$, while in the river it remains between 120 $190 \mu \mathrm{Scm}^{-1}[3]$. Due to the range of tides ( $4.4 \mathrm{~m}$ at high tide to $0.71 \mathrm{~m}$ at low tide), the estuary is classified as a meso-tidal estuary [1].

The river presents a variety of islands in its course, with mainly sandy soils and bottoms. Among them, the island of La Paloma is located in the middle estuary and, it has the highest specific surface pore diameter [4]. Within the area of study, the river receives freshwater discharges from major tributaries, in addition to minor discharges coming from small towns located on the verge. These minor discharges come mainly from major sources of managed channels: (1) agricultural drains, (2) storm drains (3) sewage treatment plant drainages (STP), and the groundwater discharge from irrigation zones [4] from the surrounding Guardia Mitre, Zanjon Oyuela, Viedma and Carmen de Patagones, which are cities located

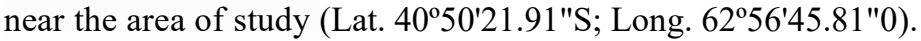

The nitrogen $(\mathrm{N})$ and phosphorus $(\mathrm{P})$ concentrations present in the river have only been studied by government entities. In the last years, the river has experienced levels of low 
transparency in the area, as revealed by a Secchi depth about $0.4 \mathrm{~m}$ in summer and $1.0 \mathrm{~m}$ in spring [5], increased sites of sedimentation and re-suspension of sediments and visible surface foams. With the hypothesis that the urban discharges are the main sources of nutrients generating effects or consequences to the ecosystem [6], we evaluated nutrient distributions and temporal patterns of change using the molar concentration average and some environmental factor correlations.

\section{METHODS}

\subsection{Data collection}

All sampling was realized during 2013 and 2016, in the river zone and external estuary to the South-East Río Negro and South Buenos Aires Provinces, Argentina (Fig. 1). In situ levels of $\mathrm{pH}$, temperature, dissolved oxygen (DO) and conductivity were measured during the first 2 hours of high tide using a water quality meter (Sper Scientific Ltd., 850081).

On the other hand, water samples were collected for later nutrient analyses, and nitrogen $(\mathrm{N})$ and phosphorus $(\mathrm{P})$ in dissolved forms. These samples were filtered through glass microfiber filters (Whatman ${ }^{\mathrm{TM}} \mathrm{GF} / \mathrm{C}$ ) and stored at $-18^{\circ} \mathrm{C}$ until analysis by standardized procedures from Standard Methods for the Examination of Water and Wastewater [7]. Nutrients, according to the methods, were analysed colorimetrically (Cole Palmer 2100UV spectrophotometer 2009): $\mathrm{N}^{-\mathrm{NH}_{4}}$ by phenol salt method reading at $630 \mathrm{~nm} ; \mathrm{N}-\mathrm{NO}_{3}$ by UV methods readings at $220 \mathrm{~nm}$ and $275 \mathrm{~nm}$, in order to discount organic matter absorption; and $\mathrm{N}_{-} \mathrm{NO}_{2}$ by sulphanilamide reaction and $\mathrm{N}-(1-$ naphthylethylenediamine) $\lambda \max$ of azo-dye at $543 \mathrm{~nm}$. On each sampling date, a transverse area was covered from 30-60 km, and on each site, there were 3-5 samples taken.

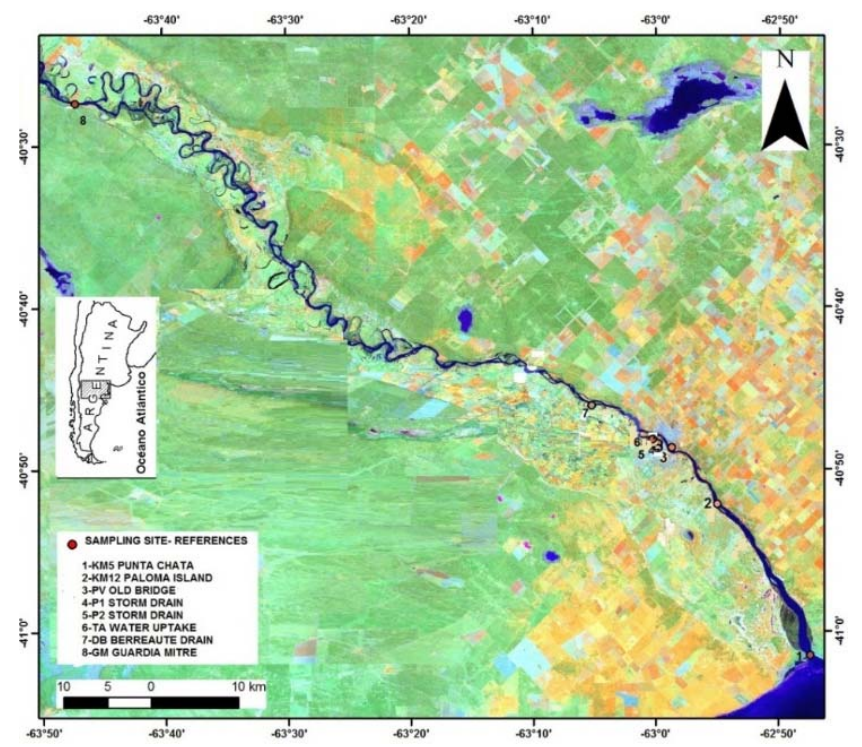

Figure 1: Map of the Negro river estuary and sampling sites. 


\subsection{Statistics and data expression}

The data was tested by analysis of variance (ANOVA) employing Software Info stat [8] and the Tukey test to obtain the significant difference between seasons $(p<0.05)$. A correlation matrix was calculated for both nutrients, for all the measured parameters. To find or to interpret spatial trends, we executed multivariate analyses.

\section{RESULTS}

The 2013-2016 seasonal averages of TDN and TDP that were measured as a discrete sampling program are shown in Fig. 2, Fig. 3 and Fig. 4. The statistical analysis allowed us to observe the seasonal and spatial variability of the chemical system of the Negro river's tidal plain estuary.

\subsection{Hydro chemical factors}

The ANOVA analysis of hydro chemical factors determined the seasonal fluctuations for all parameters measured $(p<0.0001)$. Only the spring salinity mean differed significantly from the measurements during the rest of the seasons throughout the year (Fig. 2, Fig. 3 and Fig. 4). Salinity was lower in the GM site, reflecting the larger river input, with a mean of $0.090 \%$; whereas a gradient of the salinity mean was recorded to $12 \mathrm{DB}-\mathrm{km}$ for about $0.13-0.16 \%$, reflecting an intrusion of salty waters. Only at $5 \mathrm{~km}$ were we presented with a mean of $3.9 \%$, which represented significant differences with the rest of the sites, reflecting an intrusion of salt from ocean water.
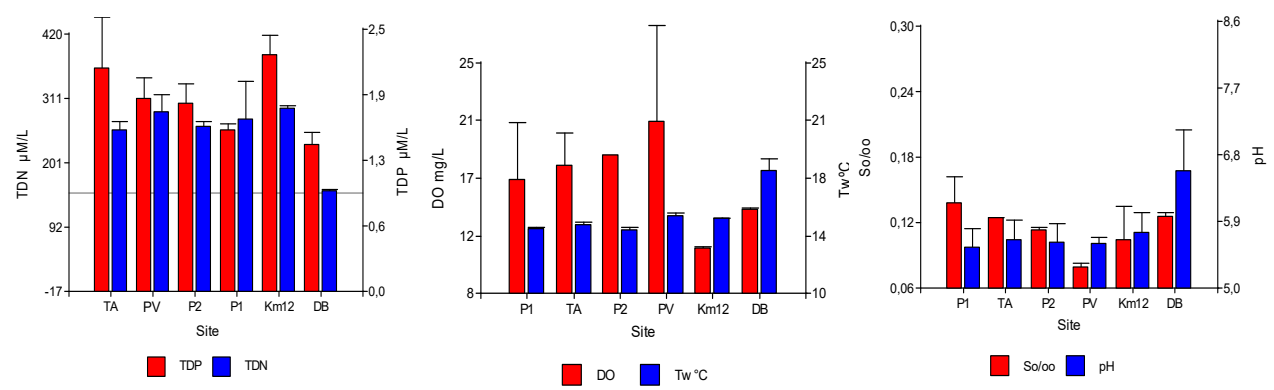

Figure 2: Variation, environmental variables $(n=3-5)$, SD Season: Winter.
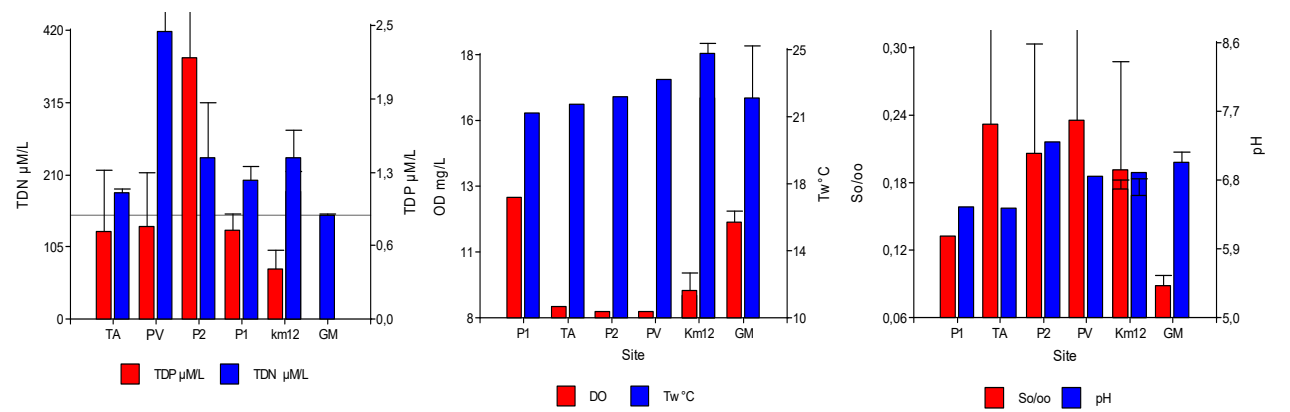

Figure 3: Variation, environmental variables $(n=3-5)$, SD Season: Summer. 

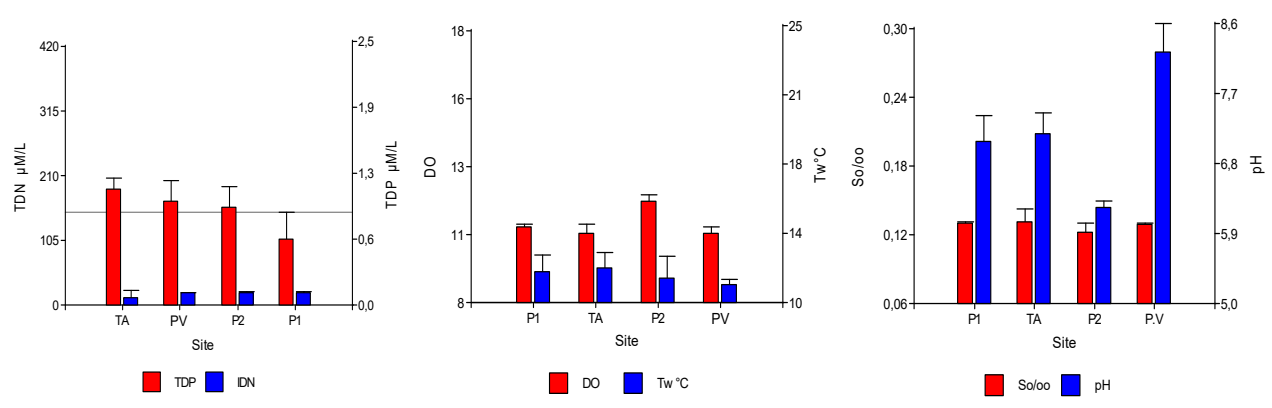

Figure 4: Variation, environmental variables $(n=3-5)$, SD Season: Autumn.

The temperature measurement revealed temporal variability, with the highest means values in summer, $23.2^{\circ} \mathrm{C}$, and the lowest in winter $11.8^{\circ} \mathrm{C}$ (Fig. 3 and Fig. 5). Regarding spatial variability, the highest temperature was measured in site close to discharge domestic effluents on $12 \mathrm{~km}$.

The dissolved oxygen, as expected, had an inverse correlation with temperature (Table 1): the highest mean values were determined for the autumn season, and in the remaining seasons of the year, the differences in that parameter were not significant.

In autumn, these waters registered the lowest mean for $\mathrm{pH}$ levels, in the order of 5.9 (range 5.4-6.1) (Table 1 and Fig. 5).

Salinity and $\mathrm{pH}$ had an inverse annual correlation observed with $\mathrm{N}^{-\mathrm{NO}_{3}}$ and with the concentration of $\mathrm{P}_{-} \mathrm{PO}_{4}^{-3}$ (Table 1).

\subsection{Temporal variability of nutrients}

The ANOVA analysis of TDN showed seasonal differences (Table 2). Spring data had significant differences with the highest values of TDN taken in autumn and summer, although these levels were obtained only in the $5 \mathrm{~km}$ at the beginning of the external estuary, suggesting that the site is important for removal to the atmosphere [12] or its uptake by species of plankton (TDP dates not measured in spring). The TDP concentrations in autumn
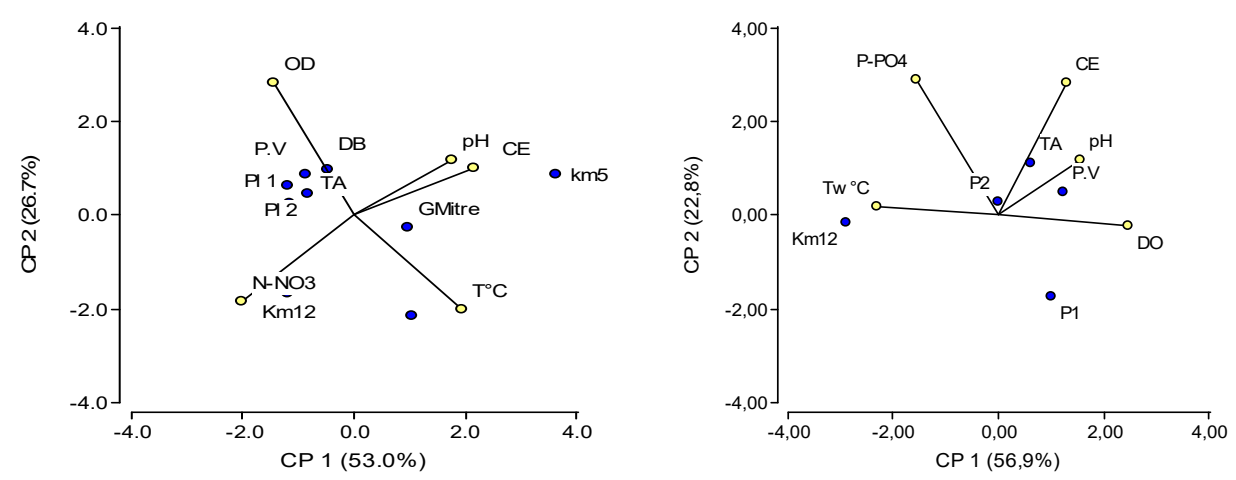

Figure 5: ACP of sources of nutrients and environmental variables, in the Negro river Estuary. 
Table 1: Correlation coefficients (r) between physico-chemical characteristics of the subsuperficial waters and dissolved nutrients, in $\mathrm{mg} / \mathrm{L}$.

\begin{tabular}{|l|c|c|c|c|c|c|c|}
\hline & $\mathrm{N}^{-N O}{ }_{3}$ & $\mathrm{P}_{-} \mathrm{PO}_{4}$ & $\mathrm{~S} \%$ & $\mathrm{~km}$ & $\mathrm{pH}$ & $\mathrm{DO}$ & $\mathrm{T}^{\circ} \mathrm{C}$ \\
\hline $\mathrm{N}-\mathrm{NO} 3$ & 1.00 & 0.04 & & & & & \\
\hline $\mathrm{P}-\mathrm{PO} 4$ & 0.34 & 1.00 & & & & & \\
\hline $\mathrm{S} \%$ o & $-0.36^{*}$ & -0.25 & 1.00 & & & & \\
\hline $\mathrm{km}$ & 0.02 & -0.23 & $-0.32^{*}$ & 1.00 & & & \\
\hline $\mathrm{pH}$ & $-0.55^{* *}$ & $-0.50^{*}$ & 0.18 & 0.15 & 1.00 & & \\
\hline $\mathrm{DO}$ & $0.31^{*}$ & 0.30 & -0.15 & 0.11 & $-0.60^{* *}$ & 1.00 & \\
\hline $\mathrm{T}^{\circ} \mathrm{C}$ & 0.22 & 0.04 & 0.22 & 0.07 & 0.19 & $-0.40^{*}$ & 1.00 \\
\hline
\end{tabular}

Indicates significance: ${ }^{*} p<0.05$ and ${ }^{* *} p<<0.001$.

Table 2: Mean adjusted by season. $\mathrm{N}$ and $\mathrm{P}$ in $\mu \mathrm{mol} / \mathrm{L}$ and LSD Fischer test $\alpha=0.05$.

\begin{tabular}{|c|c|c|c|c|c|c|c|c|c|c|c|c|}
\hline \multirow[t]{2}{*}{ Season } & \multicolumn{2}{|l|}{ TDN } & \multicolumn{4}{|c|}{$\begin{array}{l}\text { Matrix of differences between } \\
\text { means }\end{array}$} & \multicolumn{2}{|l|}{ TDP } & \multicolumn{4}{|c|}{$\begin{array}{l}\text { Matrix of differences between } \\
\text { means }\end{array}$} \\
\hline & Mean & $\mathrm{SE}$ & Wint. & Aut. & Spr. & Summ. & Mean & $\mathrm{SE}$ & Wint. & Aut. & Spr. & Summ. \\
\hline Wint. & 19.4 & 21.0 & & $*$ & & $*$ & 0.93 & 0.18 & & $*$ & & \\
\hline Aut. & 245.9 & 16.3 & & & $*$ & & 1.82 & 0.14 & & & & $*$ \\
\hline Spr. & 3.8 & 32.6 & & & & $*$ & wd & wd & & & & \\
\hline Summ. & 211.5 & 16.3 & & & & & 1.01 & 0.19 & & & & \\
\hline
\end{tabular}

doubled the levels of summer and winter, which did not present significant differences. For $\mathrm{N}-\mathrm{NH}_{4}$, there were some records in summer in the order of $86-74 \mu \mathrm{mol} / \mathrm{L} \mathrm{N}-\mathrm{NH}_{4}(\mathrm{P} 1$ was $29 \%$ of NID and PV, respectively, represented $12 \%$ of NID) and in the order of $<0.71 \mu \mathrm{mol} / \mathrm{L}$ in the river area (GM) in late autumn.

\subsection{Nutrients and trophic conditions}

The high nutrient concentrations of nutrients detected (Table 1, Fig. 3 and Fig. 4) corroborated the impact of the sources [9]. The ACP analysis (Fig. 5) of $\mathrm{N}-\mathrm{NO}_{3}$ showed four kinds of sites than in descending levels of $\mathrm{N}-\mathrm{NO}_{3}$ are:

- Middle estuary, at $12 \mathrm{~km}$, close to discharges from domestic effluents that are likely the main source of nitrates.

- Inner estuary, several urban discharge channels and sites to water uptake for human consumption (P1, P2, TA and DB, PV)

- $\quad$ Fluvial area, Guardia Mitre (GM)

- External estuary, at the $5 \mathrm{~km}$ fishing area 
The ACP analysis of $\mathrm{P}_{-} \mathrm{PO}_{4}$ showed inputs from two main sites that where the highest values were in middle estuary, at $12 \mathrm{~km}$ and the water uptake area, and the lowest at the inner estuary, with the urban discharge channel P1. These results confirm nutrient enrichment.

\section{DISCUSSION}

In the absence of the other tributaries and from freshwater to the inner estuary, salinities were conserved annually and differed significantly from those of the mixing zone $(5 \mathrm{~km})$. Independently of the season [14], these results permitted spatially for a physical classification of the river's Río Negro estuary, according to the distribution of salinities and tides, into three bands [3].The first was characterised by freshwater $(<0.2)$, the second by tidal and oligohaline $(0.2-1.3)$, and the third by tidal and mesohaline $(1.3-18)$ [13]. In this work, we have found that anthropogenic inputs from the middle to inner estuary had a major influence on the distribution of nitrate, and had minor effects on phosphate distribution. Inversely to what was detected in the past in the Tamar estuary, was that the tributary was the main source for this nutrient [14].

With regards to TDN, these results being in a range between $149-350 \mu \mathrm{molL}^{-1}$ could be evidence of high-river discharge under full tide conditions. Those discharges were given at the end of summer and the beginning of autumn, while the lowest ones were given in winter (for about 18-20 $\mu \mathrm{molL}^{-1}$ ). Considering this, and in addition to $\mathrm{pH}$ in descendant temperature increasing these measurements, could be considered as related aspects attributed to oxidative processes of organic matter degradation that would be in constant entry to the estuary while it discharges [9].

The TDP concentrations followed similar trends to other environments: increased values throughout summer and into early autumn in a range of $1.3-2.6 \mu \mathrm{molL}^{-1}$ to fall afterwards, during the winter, to a range of $0.3-1.2 \mu \mathrm{molL}^{-1}$. These levels were found, for example, from the wet to the dry period in the Sao Francisco River, Brazil, and other freshwater environments [9], [10].

The occurrence of water eutrophication is actually a complex function of all the possible influencing factors. Water eutrophication has advanced from simple individual parameters like total phosphorus and total nitrogen. The preliminary results obtained in this work showed the system as eutrophic to highly eutrophic, respectively [11]. Other influencing factors on water eutrophication [11] besides the nutrient enrichment found in this work were environmental factors, such as: temperature, salinity, $\mathrm{pH}$, and microbial activity, as was measured by previous work [15].

\section{ACKNOWLEDGEMENTS}

Thanks go to Río Negro National University, for the financial support of research projects PI40C-406 and PI40C-155, and to the Secretary of our Investigation, Marta Borda.

\section{REFERENCES}

[1] Piccolo, M.C. \& Perillo, G., El mar argentino y sus recursos pesqueros: Geomorfología e Hidrografía de los estuarios, ed. E. Boschi, INIDEP: Mar del Plata, pp. 133-161, 1997.

[2] Abrameto, M. et al., Agua Subterránea recurso estratégico. Tomo II. Caracterización química e isotópica preliminar del agua superficial y subterránea en el Valle inferior del río Negro, eds. N. González, E.E. Kruse, M.M. Trovatto, P. Laurencena, Argentina, pp. 29-34, 2013, Online. http://sedici.unlp.edu.ar/handle/10915/30329. Accessed on: Mar. 2017. 
[3] Elliott, M. \& McLusky D.S., The need for definitions in understanding estuaries estuarine, coastal and shelf science, 2002, Online http://www.academia.edu/30483064/

The_Need for_Definitions_in_Understanding_Estuaries. Accessed on: Mar. 2017.

[4] Abrameto, M., Barrio, D., Banzato, L., Fellenz, N., Gibeli, T. \& Marcovecchio, J., Niveles de metales traza en invertebrados colectados en el río negro II Reunión argentina de la Geoquímica de la Superficie [Levels of trace metals in invertebrates collected in the river Río Negro. Second Argentine Meeting of the Geochemistry of Surface Waters], pp. 1-5, 2012.

[5] Hunicken, L., Dinámica poblacional de la almeja asiática, Corbicula fluminea (Müller 1774), en la zona inter mareal del Valle Inferior del río Negro [Population dynamics of the Asiatic clam, Corbicula fluminea in the intertidal zone of the lower valley of the Black river], University of Buenos Aires, 2015.

[6] Camargo, J. \& Alonso A., Contaminación por nitrógeno inorgánico en los ecosistemas acuáticos: problemas medioambientales, criterios de calidad del agua, $e$ implicaciones del cambio climático [Inorganic nitrogen contamination in the aquatic ecosystems: environmental problems, water quality criteria, and implications of climate change], Ecosistemas, 16(2), pp. 98-110, 2007.

[7] A.P.H.A., Standard methods for the examination of water and wastewater, 17, Washington D.C., p. 1193, 1989.

[8] Di Rienzo, J.A., Casanoves, F., Balzarini, M.G., Gonzalez, L., Tablada, M. \& Robledo, C.W., 2015, Universidad Nacional de Córdoba, Argentina, Online. http://www.infostat.com.ar. Accessed on: Mar. 2017.

[9] Rodrigues, R.P., Knoppers, B.A., Landim de Souza, W.F. \& Sabadini Santos, E., Suspended matter and nutrient gradients of a small-scale river plume in Sepetiba Bay, SE-Brazil. Brazilian archives of biology and technology: Curitiba, 52(2), pp. 503-512, 2009. Online, http://www.scielo.br/scielo.Accessed on: Mar. 2017.

[10] Zirino, A., Elwany, H., Facca, C.H., Maicu, F., Neira, C. \& Mendoza, G., Nitrogen to phosphorus ratio in the Venice (Italy) Lagoon (2001-2010) and its relation to macroalgae. Marine Chemistry 180, pp. 33-41, 2016.

[11] Yang, X., Wu, X., Hao, H. \& He, Z., Mechanisms and assessment of water eutrophication, Journal Zhejiang University Science B, 9(3), pp. 197-209, 2008.

[12] Burgin, A.J, \& Hamilton S.K., Have we overemphasized the role of denitrification in aquatic ecosystems? A review of nitrate removal pathways. Frontiers in Ecology and the Environment, 5(2), pp. 89-96, 2007.

[13] Chainho de Olivera, P.M., Contribution to the development of biotic integrity assessment tools for Portuguese estuaries based on benthic communities, University of Lisbon, Portugal, 2008, Online. http://repositorio.ul.pt/bitstream/10451/1691/1/ 3712 Tese Chainho. Accessed on: Mar. 2017

[14] Morris, A.W., Bale, A.J. \& Howland, J.M., Nutrient distributions in an estuary: evidence of chemical precipitation of dissolved silicate and phosphate. Estuarine, Coastal and Shelf Science, 12, pp. 205-216, 1981.

[15] Cambruzzi, N., Abrameto, M. \& Abate, S., Indicadores de contaminación fecal en el estuario del río Negro: comparación entre Escherichia coli y Enterococos [Fecal contamination indicators in the Rio Negro river estuary: comparison between E. coli and Enterococci], 2016, p. 17, Online. http://www.cnea.gov.ar/cac/ices/encuentros/eices11/PROGRAMA-E-ICES\%2011.pdf. Accessed on: Mar. 2017. 